NBER WORKING PAPER SERIES

\title{
A GLIMPSE INTO THE WORLD OF HIGH CAPACITY GIVERS: EXPERIMENTAL EVIDENCE FROM A UNIVERSITY CAPITAL CAMPAIGN
}

\author{
Tova Levin \\ Steven D. Levitt \\ John A. List \\ Working Paper 22099 \\ http://www.nber.org/papers/w22099 \\ NATIONAL BUREAU OF ECONOMIC RESEARCH \\ 1050 Massachusetts Avenue \\ Cambridge, MA 02138 \\ March 2016
}

Special thanks to Joseph Buck and Jim Bruecker of the University of Chicago Booth Business School for allowing us access to their donor pool and for partnering on this project. The views expressed herein are those of the authors and do not necessarily reflect the views of the National Bureau of Economic Research.

At least one co-author has disclosed a financial relationship of potential relevance for this research. Further information is available online at http://www.nber.org/papers/w22099.ack

NBER working papers are circulated for discussion and comment purposes. They have not been peer-reviewed or been subject to the review by the NBER Board of Directors that accompanies official NBER publications.

(C) 2016 by Tova Levin, Steven D. Levitt, and John A. List. All rights reserved. Short sections of text, not to exceed two paragraphs, may be quoted without explicit permission provided that full credit, including $\odot$ notice, is given to the source. 
A Glimpse into the World of High Capacity Givers: Experimental Evidence from a University

Capital Campaign

Tova Levin, Steven D. Levitt, and John A. List

NBER Working Paper No. 22099

March 2016

JEL No. C93,H4

\section{ABSTRACT}

The wealthiest $10 \%$ of donors now give $90 \%$ of charitable dollars in the U.S., but little is known about what motivates them. Using a natural field experiment on over 5,000 high capacity donors, we find persistence in giving patterns, that signals of program quality influence giving, and that the price of giving is not unduly important. Unlike typical small donors, our givers respond only on the intensive margin, and often with a longer time lag. Our study highlights the value to practitioners of partnering with academics, as our intervention has generated $\$ 30$ million in incremental donations to the University.

Tova Levin

University of Chicago

5750 Woodlawn

Chicago, IL, 60637

TLevin@humana.com

Steven D. Levitt

Department of Economics

University of Chicago

1126 East 59th Street

Chicago, IL 60637

and NBER

slevitt@midway.uchicago.edu
John A. List

Department of Economics

University of Chicago

1126 East 59th

Chicago, IL 60637

and NBER

jlist@uchicago.edu 
As federal, state, and local budgets continue to tighten, the provision of public goods by charitable organizations has increased dramatically. Total charitable gifts of money have roughly doubled in real terms since 1990 in the U.S., and the number of nonprofits grew by nearly 60 percent from 1995-2005 (see Andreoni, 2006). The import of non-profit fundraising is witnessed in a wide variety of sectors. Non-profit hospitals and healthcare systems raised more than $\$ 9$ billion in 2013, and there were 36 capital campaigns at colleges and universities in 2014 targeting \$1 billion or more in donations.

One of the dominant features of the charitable sector is the large and increasing fraction of overall donations coming from the wealthiest donors. Havens and Schervish (1999) report that households in the top 1 percent of the income distribution (annual income above $\$ 250,000$ in 1994) provided 33 percent of the total charitable dollars in 1995. Auten, Clotfelter, and Schmalbeck (2000) note that the wealthiest 1.4 percent of decedents are responsible for 86 percent of charitable giving from bequests. These patterns have become even more extreme in recent years. For example, what used to be known as the "80/20 rule" - that 20 percent of the donors provide 80 percent of the money - has become the 90/10 rule, or even the 95/5 rule (Worth, 2015). Almost all previous academic research, however, has focused on the motivations of "ordinary" or "modal" givers (see, e.g., List and Lucking-Reiley, 2002, and Frey and Meier, 2004, for early work). Answering the same questions for the very wealthy has gone unexplored.

This study takes this step by using a natural field experiment to explore what motivates high capacity donors. ${ }^{1}$ Our partnership is with the University of Chicago Booth School of Business, which sends an average of four donation request letters per year to the individuals in our sample. We were permitted access to use one such mailing, in the Fall of 2009, for a natural field experiment. Each of the nearly

\footnotetext{
${ }^{1}$ Related work by Andreoni, et al. (2015), Eckel et al. (2015), and Kessler, et al. (2015) also explores high capacity donors.
} 
6,000 potential donors in our sample was assigned to one of five different treatment cells or to the control group. In an effort to provide a direct link with the current literature, we follow two approaches in our design. First, we use both a warm and a cold list of potential donors, as in Landry et al. (2007). Second, in the five treatments we varied both the price of the good - through different match rates, consistent with Karlan and List (2007) - and used various signals of charitable quality_via the use of donor gifts and available match dollars (see Landry et al., 2007). By using these treatments, we learn about certain motivations of high capacity donors, while simultaneously measuring if the insights in the received literature generalize smoothly to a high capacity donor pool.

Another unique feature of our data is that we are permitted a chance to track the potential donors over a $3 \frac{1}{2}$ year period, allowing us to go beyond measurement of short run substitution effects and determine if long run giving patterns are influenced by treatment. We report several insights. First, our treatments generated over \$30 million in incremental donations to the University. This result, in and of itself, lends credibility to using science to further philanthropic efforts. Second, in many ways high capacity donors are similar to modal donors: warm list people are much more likely to give than those on the cold list, signals of program quality (match dollars and donor gifts) influence high capacity donors, and the price of giving (different match rates) is not unduly important. Third, we find some evidence of donor fatigue: too many contacts to high capacity donors can be detrimental to fundraising efforts.

While these insights provide some tentative support for the notion that the received results in the literature might generalize to the right tail of the donor distribution, there are important differences. First, most of the effects for modal donors reported in the literature occur on the extensive margin whereas for high capacity donors the treatment effects we find largely revolve around moving the 
intensive margin. Second, while the treatment effects reported in the literature are typically drawn from gift differences within days or weeks of the intervention, our data suggest small treatment effects in the first few months but large effects over several years. This result suggests that there is much to gain by moving from an experimental strategy that measures short run substitution effects to one that measures long run impacts.

The remainder of our note proceeds as follows. Section 2 summarizes our experimental design. Section 3 discusses the experimental results. Section 4 concludes.

\section{II: Experimental Design}

In October 2009, we partnered with the Booth Business School at the University of Chicago, a non-profit in Illinois, to run a natural field experiment involving their high net wealth donor pool. The sample included nearly 6,000 individuals, approximately $48 \%$ percent of whom had made at least one gift in the two years prior to our experiment. In a typical year our subjects' aggregate donation amount to the school is roughly $\$ 20$ million. According to the Booth school's charity model estimates, our donor sample has a median annual giving capacity greater than $\$ 25,000$.

The institution sends an average of four donation request letters per year to our sampled individuals. We were allowed to use random assignment on one such mailing in the Fall of 2009. Each of the 5,675 potential donors in our sample was assigned to one of five different treatment cells or to the control group. We chose the various treatments to provide a direct link to the literature, which has reported estimates of how program quality can influence givers as well as how changes in prices via different match rates can influence givers. For instance, Landry et al. (2007) report that various mechanisms can be used to create an enduring signal of 
charitable quality. In their model, any upfront money - used for donor gifts, a match program, etc.- - can serve to signal that the specific fund raising drive is a high quality effort. Note that even though the potential donors likely understand the quality of the overall institution itself, it is the specific fundraising drive for which these signals might have import. Landry et al. (2007) find that years after the actual signal is sent they observe treatment effects for the modal giver. In terms of different match rates, Karlan and List (2007) report that even though the availability of match dollars has value, the rate itself does not have a significant impact on donors.

In the spirit of this literature, we design treatment groups varying these elements. First, all of the 5,675 potential donors received a variant of a donation request letter written by Steven Levitt (see Appendix A for the full text of the baseline letter). In the treatment we denote as "SIGNED BOOK," subjects also received a signed copy of SuperFreakonomics (co-authored by Steven Levitt, and which had just been published) along with the letter. In a second treatment, "SPEAKING INVITATION," individuals received an invitation to hear either Steven Levitt or his co-author Stephen Dubner speak at one of their upcoming engagements. A third treatment "SIGNED BOOK AND SPEAKING INVITATION" provided both a signed book and an invitation to attend a lecture. In all three treatments, the gifts were unconditional, i.e. they did not depend on whether the donor gave or not.

The final two treatments did not involve books or invitations, but rather, offered either a 1-1 match ("ONE TO ONE MATCH”) or 2-1 match ("TWO TO ONE MATCH") for any gift that was made after the receipt of the letter but before the end of 2009. To ensure the alumni understood the effects of the match, we included a sentence that stated the match would effectively double (or triple, in the 
case of the 2-1 match) the amount of the donation. Finally, there was a control group that received a letter, but no book, no invitation, and no matching promise. ${ }^{2}$

For each of the subjects, we know their state of residence, whether they had received a degree from the University of Chicago (and if so when they earned that degree), whether they had given a gift in the last two years, the size of gifts within the last two years, the development office's estimate of that subject's giving capacity, and the number of mailings sent by the institution to the subject in the previous two years. About one-fourth of the subjects live in Illinois; 95 percent received an MBA.

Table 1 shows the extent to which our six assignment groups are balanced on the observable characteristics. Each column of the table reports the results of a different regression, where the dependent variable is provided at the top of the column and the right hand side variables are treatment indicators. Column 1, for instance, presents results for an indicator variable of whether the subject made a donation to this institution in the prior two years. The control group is the omitted category; thus the coefficient on the constant is the mean value of the dependent variable for the control group. The coefficient on a particular treatment is the mean difference relative to the control group, with the associated standard error in parentheses.

As the results of Table 1 demonstrate, our groups are well balanced. Only one of the thirty coefficients on the treatment groups is statistically significant at $p$

\footnotetext{
${ }^{2}$ The book and invitation treatments have a smaller number of subjects than the matching treatments because of concerns in the development office about the workload associated with packaging and mailing the signed books, and concerns about accommodating large numbers of donors at future speaking events. The latter concern turned out to be unfounded, as very few of the treatment subjects chose to attend an event. There were slightly more than 200 individuals in each of the treatments involving a book or invitation, roughly 1,700 individuals in each of the matching treatments and the control group.
} 
$<.05$ - roughly what one would expect in a balanced sample. It is worth noting, however, that due to the lumpiness of gifts, rather large mean differences in past gift sizes are present across some of our treatments. There is high variance across gifts, however, so these differences are not unexpected. In the analysis that follows, we include specifications that control for all of these observables and given the lumpiness of data focus on long run treatment effects.

\section{III: Experimental Results}

Table 2 reports the impact of our treatments on total giving (Appendix B contains results during the experimental window). Each column of Table 2 corresponds to a different regression. In each case, the dependent variable is the total amount of money donated by an individual between November 1, 2009 (the time of our intervention) and June 2013 (the latest data available to us). Columns 1 and 2 of Table 2 pool our five treatments; columns 3 and 4 report each of the treatments separately. In all columns, the omitted category is the control group.

We present empirical results both with no controls (columns 1 and 3) and including controls (columns 2 and 4). The variables included as controls are the dollar value of donations by that individual in the preceding two years, an indicator for whether the individual had given in the preceding two years, a dummy for the subject's giving capacity as measured by the institution, whether the individual resides in Illinois, whether the alum graduated from the full-time MBA program, or a different program, and the number of mailings the institution sent the subject during the year of the experiment. We report the coefficients on all controls except for the categorical variable for giving capacity which takes on 19 different values.

Focusing first on the pooled results in columns 1 and 2 of Table 2, we find that exposure to our treatments led to an average increase in giving of roughly $\$ 6,500$ per person in the raw data and over $\$ 8,000$ with controls. In spite of the 
huge magnitude of these coefficients - those in the treatment group gave on average more than twice as much as the those in the control group over the next three and one half years - the estimates are only borderline statistically significant at conventional levels. Gifts from these high wealth donors have a long right tail, which makes it difficult to estimate treatment effects with precision.

There are two control variables that are statistically significant: being on the institution's warm list (i.e. having donated in the previous two years), which has the expected positive effect, and the number of mailings sent in the previous year, which has a negative, albeit small, effect. Larger previous gifts, living in the same state as the institution, and being an alum all carry positive but statistically insignificant coefficients.

Columns 3 and 4 present results broken down by individual treatment. Estimated coefficients on the two treatments that include books and the one-to-one match are relatively small in magnitude, statistically insignificant, and flip sign when controls are added. The other two treatments - speaking invitation and twoto-one match - carry large positive coefficients and are statistically significant at the $p<.05$ and $p<.01$ levels respectively. Given the size of the standard errors, one cannot reject the null hypothesis that the coefficients on the book treatments and the speaking invitation-only treatments are the same, but at least directionally, it appears that the recipients were not very fond of Superfreakonomics.

Table 3 further explores the sensitivity of the experimental results to outliers, the time window post-intervention, sub-groups of donors, and more extensive controls. The six columns of Table 3 correspond to the pooled treatment (column 1) and the five individual treatments (columns 2-6). Each row reflects a different cut of the data. For purposes of comparison, the top row of Table 3 presents our baseline estimates, including covariates, from Table 2. So, for 
instance, the coefficient in the first column and first row of this table, 8,737, matches the coefficient at the top of column 2 in Table 2.

Row two in Table 3 shows the sensitivity of our results to excluding the largest post-period donor from our sample. This individual, who was in the twoto-one match treatment, gave a single gift of $\$ 10$ million. ${ }^{3}$ The pooled treatment estimate falls roughly in half, but remains significant at the $p<.05$ level because the standard error falls as well. The two-to-one match coefficient falls, as would be expected, but remains significant at conventional levels. The coefficient estimates on the other treatments also all are reduced, despite the fact the large donor was not part of these treatments (the treatments are mutually exclusive). Omitting this donor indirectly affects the other coefficients through his impact on the coefficients on the covariates.

The third row of Table 3 further explores the impact of outliers more generally, capping the value of post-period gifts at $\$ 1$ million. This cap binds on 15 subjects, translating to $0.26 \%$ of our sample, or $0.62 \%$ of members who donated during the post-period. All of the estimated values fall substantially, demonstrating that much of the effect we observe in our data is operating through the channel of gifts over \$1 million in value. Whether we were "lucky" that these large gifts were concentrated in the treatment subjects, or whether our treatments truly contributed to these large gifts is a question we cannot definitively answer.

The fourth row of Table 3 includes a fuller set of controls: indicators for each subject's graduation decade and whether the alum received an MBA. The effects are very similar to the baseline results, both in magnitude and significance.

\footnotetext{
${ }^{3}$ This gift came after December 31, 2009, the end of the period which had two-to-one matching, so was not matched.
} 
The next two rows divide gifts by the timing of whether they were received in 2009 (the two months after our mailing) or later. This distinction is particularly relevant to the matching treatments, because the matches were only promised if the gift was received in 2009. Surprisingly, we find that little of the effect, even for the matching treatments, comes within the matching window. The matching programs did not succeed in triggering large, immediate gifts. Further, consistent with the extant literature, within the matching window the match rate does not affect donors (see Karlan and List, 2007). Yet, in the long run having a match does induce more philanthropic dollars, which is consonant with upfront monies serving to signal the quality of the program (see Landry et al., 2007 and Karlan and List, 2007).

Distinguishing between warm list and cold list demonstrates that all benefits to the institution are concentrated among those on the warm list. This result is in concert with the literature, which shows the importance of having a warm list (see Landry et al. 2007). Our effects are driven by those donors with the highest giving capacity, consistent with the shrinkage in the estimates earlier in the table when we capped large gifts. Treatment effects do not appear to vary sharply according to the current state of residence of the donor.

All of the results presented thus far can operate through two different possible channels: (1) changing the likelihood of a gift or (2) altering the size of the gift conditional on giving. The final row of Table 3 isolates only the latter channel, by restricting the sample only to the roughly $42 \%$ percent of the sample who made a donation in the post period. The standard errors become quite large in some columns. The pooled treatment effect estimate is almost unaffected. Our interventions appear to have primarily altered the size of gifts conditional on giving, 
rather than the likelihood of a gift. ${ }^{4}$ This result represents a major departure from insights gained from natural field experiments that explore giving patterns of modal givers, where the treatment effects tend to be driven by the extensive, rather than intensive, margin (see the summary in List, 2011). Our results are consistent with the notion that increased giving occurs because our highest capacity givers donate more due to treatment.

\section{Conclusion}

This paper reports the results of a natural field experiment targeting highwealth donors. Those exposed to our treatments have given an average of more than $\$ 8,000$ to the institution in the ensuing years compared to the control group. Taken literally, our intervention generated over $\$ 30$ million in incremental donations to the institution. Interestingly, treatment effects are concentrated amongst those donors with the highest giving capacity and those who had given to the institution in the preceding two years. In this way, our treatment effects come from larger gifts conditional on giving, rather than through changes in the probability of a gift being made.

Our results have import for academics, practitioners, and policymakers. For academics, the finding that in many ways high capacity donors are similar to the modal donor provides some tentative support for the notion that the received results in the literature might generalize to the right tail of the donor distribution. Much more work needs to be done to make any definitive statements, as we do find some important differences across sampled populations. For practitioners, this study provides key evidence that science can inform their efforts, even for high capacity donors. In this manner, the effect on donor fatigue has immediate implications, as

\footnotetext{
${ }^{4}$ The coefficients on probability of donating for both the pooled treatments and the individual treatments range between 0 and -.051 , all of which are insignificant, when including controls.
} 
do the insights gained on matches and donor gifts. For policymakers, as we begin to understand the motivations of high capacity donors, we can start to provide evidence necessary to calculate the benefits and costs of proposed policies.

\section{References}

Andreoni, James, (2006) "Philanthropy," Handbook of the Economics of Giving, Altruism, and Reciprocity, Ch. 18, 2: 1201-1269.

Andreoni, James, Nikos Nikiforakis, and Jan Stoop, (2015), "Blessed Are the. . Rich: A Natural Field Experiment on the Kindness of the Rich and the Poor," Working Paper.

Auten, Gerald E., Charles T. Clotfelter, and Richard L. Schmalbeck, (2000), "Taxes and Philanthropy Among the Wealthy," Does Atlas Shrug? The Economic Consequences of Taxing the Rich, Ch. 12, 392-424.

Eckel, Catherine, David Herberich, and Jonathan Meer, (2015), "It's Not the Thought that Counts: A Field Experiment on Gift Exchange and Giving at a Public University," Working Paper.

Frey, Bruno S. and Stephan Meier, (2004), "Social Comparisons and Pro-Social Behavior: Testing 'Conditional Cooperation' in a Field Experiment," American Economic Review, 94(5): 1717-1722.

Havens, John J. and Paul G. Schervish, (1999), "Millionaires and the Millenium: New Estimates of the Forthcoming Wealth Transfer and the Prospects for a Golden Age of Philanthropy," Boston College Working Paper. 
Karlan, Dean and John A. List, (2007) "Does price matter in charitable giving?

Evidence from a largescale natural field experiment," American Economic

Review, 97(5): 1774-1793.

Kessler, Judd B., Katherine L. Milkman, and C. Yiwei Zhang, (2015), “Getting the One Percent to Give," Working Paper.

Landry, Craig E., Andreas Lange, John A. List, Michael K. Price, and Nicholas G. Rupp, (2007), "Toward an Understanding of the Economics of Charity: Evidence from a Field Experiment," Quarterly Journal of Economics, 121(2): 747-782.

List, J. A., A. M. Shaikh, and Y. Xu. (2016) 'Multiple Hypothesis Testing in Experimental Economics.' NBER Working paper.

List, John A. and David Lucking-Reiley, (2002), "The Effects of Seed Money and Refunds on a Charitable Giving: Experimental Evidence from a University Capital Campaign," Journal of Political Economy, 110(1): 215-233.

List, John A., (2011) "The Market for Charitable Giving," Journal of Economic Perspectives, 25(2): 157-180.

Worth, Michael J. 2015. Fundraising Principles and Practice, SAGE Publications, Inc. 


\section{Table 1: Balance of Observable Pre-Treatment Variables Relative to Control Group}

\begin{tabular}{|c|c|c|c|c|c|c|}
\hline & Warm List & Full Time & $\begin{array}{l}\text { Illinois } \\
\text { Resident }\end{array}$ & $\begin{array}{l}\text { \$ Value of } \\
\text { Gifts Two } \\
\text { Years Pre- } \\
\text { Treatment }\end{array}$ & $\begin{array}{c}\text { Giving } \\
\text { Capacity }\end{array}$ & $\begin{array}{l}\text { Mailings } \\
\text { Sent in } \\
\text { Previous } \\
\text { Year }\end{array}$ \\
\hline Signed Book & $\begin{array}{r}0.019 \\
{[0.037]}\end{array}$ & $\begin{array}{l}0.035 \\
{[0.036]}\end{array}$ & $\begin{array}{l}-0.019 \\
{[0.033]}\end{array}$ & $\begin{array}{r}-341 \\
{[7,759]}\end{array}$ & $\begin{array}{l}-0.075 \\
{[0.235]}\end{array}$ & $\begin{array}{r}0.176 \\
{[0.203]}\end{array}$ \\
\hline $\begin{array}{l}\text { Signed Book and } \\
\text { Speaking Invitation }\end{array}$ & $\begin{array}{c}0.021 \\
{[0.037]}\end{array}$ & $\begin{array}{r}0.050 \\
{[0.036]}\end{array}$ & $\begin{array}{l}-0.000 \\
{[0.033]}\end{array}$ & $\begin{array}{r}7,501 \\
{[7,810]}\end{array}$ & $\begin{array}{c}-0.092 \\
{[0.236]}\end{array}$ & $\begin{array}{r}0.146 \\
{[0.204]}\end{array}$ \\
\hline Speaking Invitation & $\begin{array}{r}0.020 \\
{[0.028]}\end{array}$ & $\begin{array}{r}-0.030 \\
{[0.027]}\end{array}$ & $\begin{array}{r}0.024 \\
{[0.025]}\end{array}$ & $\begin{array}{r}336 \\
{[5,837]}\end{array}$ & $\begin{array}{l}-0.127 \\
{[0.177]}\end{array}$ & $\begin{array}{r}0.125 \\
{[0.153]}\end{array}$ \\
\hline One to One Match & $\begin{array}{r}0.001 \\
{[0.018]}\end{array}$ & $\begin{array}{c}0.001 \\
{[0.017]}\end{array}$ & $\begin{array}{l}-0.001 \\
{[0.016]}\end{array}$ & $\begin{array}{r}5,159 \\
{[3,672]}\end{array}$ & $\begin{array}{l}-0.016 \\
{[0.111]}\end{array}$ & $\begin{array}{r}0.146 \\
{[0.096]}\end{array}$ \\
\hline Two to One Match & $\begin{array}{c}-0.002 \\
{[0.018]}\end{array}$ & $\begin{array}{c}-0.014 \\
{[0.017]}\end{array}$ & $\begin{array}{c}0.017 \\
{[0.016]}\end{array}$ & $\begin{array}{r}2,077 \\
{[3,677]}\end{array}$ & $\begin{array}{l}-0.037 \\
{[0.111]}\end{array}$ & $\begin{array}{r}0.174 \\
{[0.096]}\end{array}$ \\
\hline _cons & $\begin{array}{r}0.484 \\
{[0.012]^{* *}}\end{array}$ & $\begin{array}{r}0.623 \\
{[0.012]^{* *}}\end{array}$ & $\begin{array}{r}0.263 \\
{[0.011]^{* *}}\end{array}$ & $\begin{array}{r}6,212 \\
{[2,594]^{*}}\end{array}$ & $\begin{array}{r}11.621 \\
{[0.079]^{* *}}\end{array}$ & $\begin{array}{r}3.805 \\
{[0.068]^{* *}}\end{array}$ \\
\hline $\begin{array}{l}R^{2} \\
N\end{array}$ & $\begin{array}{r}0.00 \\
5675\end{array}$ & $\begin{array}{r}0.00 \\
5675\end{array}$ & $\begin{array}{r}0.00 \\
5675\end{array}$ & $\begin{array}{r}0.00 \\
5675\end{array}$ & $\begin{array}{r}0.00 \\
5675\end{array}$ & $\begin{array}{r}0.00 \\
5675\end{array}$ \\
\hline
\end{tabular}

$* p<0.05 ; * * p<0.01$

Notes: Each column of the table reports the results of a different regression, where the dependent variable is named at the top of the column and the right hand side variables are indicators for each of our treatments. Warm list is an indicator variable of whether the subject made a donation to this institution in the prior two years. Full time student is an indicator for whether the subject received an MBA in the full time program. The institution offers 2 part-time MBAs (evening and weekend), as well as an executive MBA, in addition to the full-time program. Illinois resident is an indicator for whether the subject currently lives in Illinois. Giving capacity represents a giving capability bracket determined by the institution. An average of 11.6 means that the average subject is rated to be able to give between $\$ 5,000$ and $\$ 25,000$. The control group is the omitted category, and the coefficient on a particular treatment is the difference in means relative to the control group, with the associated standard error in parentheses. 
Table 2: Effect of Treatment on Gift Amount

\begin{tabular}{|c|c|c|c|c|}
\hline & Gift Size & $\begin{array}{l}\text { Gift Size, with } \\
\text { Controls }\end{array}$ & Gift Size & $\begin{array}{l}\text { Gift Size, with } \\
\text { Controls }\end{array}$ \\
\hline Pooled Treatments & $\begin{array}{r}6,535 \\
{[3,378]}\end{array}$ & $\begin{array}{r}8,737 \\
{[3,779]^{*}}\end{array}$ & & \\
\hline Signed Book & & & $\begin{array}{l}-2,604 \\
{[1,954]}\end{array}$ & $\begin{array}{c}2,847 \\
{[3,230]}\end{array}$ \\
\hline $\begin{array}{l}\text { Signed Book and } \\
\text { Speaking Invitation }\end{array}$ & & & $\begin{array}{r}-3,252 \\
{[1,553]^{*}}\end{array}$ & $\begin{array}{r}1,341 \\
{[3,635]}\end{array}$ \\
\hline Speaking Invitation & & & $\begin{array}{r}8,411 \\
{[6,905]}\end{array}$ & $\begin{array}{r}12,648 \\
{[6,432]^{*}}\end{array}$ \\
\hline One to One Match & & & $\begin{array}{l}-1,652 \\
{[1,513]}\end{array}$ & $\begin{array}{r}1,109 \\
{[2,943]}\end{array}$ \\
\hline Two to One Match & & & $\begin{array}{l}16,681 \\
{[7,687]^{*}}\end{array}$ & $\begin{array}{r}17,090 \\
{[5,832]^{* *}}\end{array}$ \\
\hline $\begin{array}{l}\text { Total } \$ \text { Given in Prior } 2 \\
\text { Years }\end{array}$ & & $\begin{array}{r}0.221 \\
{[0.125]}\end{array}$ & & $\begin{array}{l}0.222 \\
{[0.125]}\end{array}$ \\
\hline Illinois Resident & & $\begin{array}{r}6,498 \\
{[4,665]}\end{array}$ & & $\begin{array}{r}6,273 \\
{[4,645]}\end{array}$ \\
\hline Warm List & & $\begin{array}{r}10,975 \\
{[3,093]^{* *}}\end{array}$ & & $\begin{array}{r}10,989 \\
{[3,101]^{* *}}\end{array}$ \\
\hline Full Time & & $\begin{array}{r}1,689 \\
{[2,414]}\end{array}$ & & $\begin{array}{r}1,914 \\
{[2,418]}\end{array}$ \\
\hline $\begin{array}{l}\text { Mailings Sent in } \\
\text { Previous Year }\end{array}$ & & $\begin{array}{r}-805 \\
{[257]^{* *}}\end{array}$ & & $\begin{array}{r}-810 \\
{[258]^{* *}}\end{array}$ \\
\hline _cons & $\begin{array}{r}6,020 \\
{[1,307]^{* *}}\end{array}$ & $\begin{array}{l}24,871 \\
{[60,373]}\end{array}$ & $\begin{array}{r}6,020 \\
{[1,308]^{* *}}\end{array}$ & $\begin{array}{l}20,957 \\
{[61,366]}\end{array}$ \\
\hline$R^{2}$ & 0.00 & 0.39 & 0.00 & 0.39 \\
\hline$N$ & 5675 & 5675 & 5675 & 5675 \\
\hline Controls & No & Yes & No & Yes \\
\hline
\end{tabular}

Notes: Table 2 reports the impact of our experimental intervention on future giving. Each column of the table corresponds to a different regression. In each case, the dependent variable is the total amount of money donated by an individual between November 1, 2009 (the time of our intervention) and June 2013 (the latest data available to us). Columns 1 and 2 pool our five treatments; columns 3 and 4 report each of the treatments separately. In all columns, the omitted category is the control group. We present the results both with controls (columns 2 and 4 ) and without controls (columns 1 and 3 ). In addition to the controls shown in the table, in columns 2 and 4 we also include indicators corresponding to each of the nineteen levels of giving capacity. Standard errors in square brackets. 


\section{Table 3: Sensitivity of the Treatment Effects to Alternative Specifications}

\begin{tabular}{|c|c|c|c|c|c|c|}
\hline & Treated & $\begin{array}{r}\text { Signed } \\
\text { Book }\end{array}$ & $\begin{array}{l}\text { Signed } \\
\text { Book and } \\
\text { Speaking } \\
\text { Invitation }\end{array}$ & $\begin{array}{l}\text { Speaking } \\
\text { Invitation }\end{array}$ & $\begin{array}{r}\text { One to One } \\
\text { Match }\end{array}$ & $\begin{array}{l}\text { Two to One } \\
\text { Match }\end{array}$ \\
\hline Baseline & 8,737 & 2,847 & 1,341 & 12,648 & 1,109 & 17,090 \\
\hline $\begin{array}{c}\quad N=5675 \\
\text { Without Largest }\end{array}$ & {$[3,779]^{*}$} & {$[3,230]$} & {$[3,635]$} & {$[6,432]^{*}$} & {$[2,943]$} & {$[5,832]^{* *}$} \\
\hline Donor & 4,474 & -258 & $-1,502$ & 9,715 & $-1,906$ & 10,927 \\
\hline$N=5674$ & {$[2,265]^{*}$} & {$[2,360]$} & {$[2,859]$} & {$[6,067]$} & {$[2,002]$} & {$[3,883]^{* *}$} \\
\hline Winsorized (1M) & 2,340 & -832 & $-1,905$ & 6,266 & $-1,173$ & 5,822 \\
\hline$N=5675$ & {$[1,428]$} & {$[1,759]$} & {$[1,579]$} & {$[4,102]$} & {$[1,405]$} & {$[2,110]^{* *}$} \\
\hline Extended Set of & 8,681 & 2,741 & 1,574 & 12,801 & 954 & 17,051 \\
\hline Controls; $N=5675$ & {$[3,768]^{*}$} & {$[3,201]$} & {$[3,682]$} & {$[6,447]^{*}$} & {$[2,906]$} & {$[5,834]^{* *}$} \\
\hline Gifts Given in & 158 & 496 & 40 & 89 & 274 & 31 \\
\hline $\begin{array}{l}\text { Matching Window } \\
\quad N=5675 \\
\text { Gifts Given after }\end{array}$ & [121] & {$[580]$} & {$[176]$} & [273] & [212] & [114] \\
\hline Matching Window & 8,489 & 2,442 & 1,519 & 12,729 & 1,020 & 16,566 \\
\hline$N=5675$ & {$[3,767]^{*}$} & {$[3,108]$} & {$[3,595]$} & {$[6,423]^{*}$} & {$[2,921]$} & {$[5,809]^{* *}$} \\
\hline Warm List & 11,447 & 1,248 & $-2,428$ & 17,470 & -28 & 24,548 \\
\hline$N=2759$ & {$[4,543]^{*}$} & {$[4,980]$} & {$[5,562]$} & {$[10,590]$} & {$[4,056]$} & {$[7,749]^{* *}$} \\
\hline Cold List & $-1,383$ & $-1,415$ & $-1,377$ & 2,985 & $-2,363$ & $-1,421$ \\
\hline $\begin{array}{r}N=2916 \\
\text { High Giving }\end{array}$ & {$[1,289]$} & {$[1,054]$} & [998] & {$[4,381]$} & {$[1,413]$} & {$[1,283]$} \\
\hline Capacity & 17,364 & 8,591 & 3,913 & 25,353 & 2,209 & 33,054 \\
\hline$N=2946$ & {$[7,464]^{*}$} & {$[6,514]$} & {$[7,411]$} & {$[12,107]^{*}$} & {$[5,715]$} & {$[11,276]^{* *}$} \\
\hline Low Giving Capacity & 392 & -588 & -417 & -114 & 753 & 351 \\
\hline$N=2729$ & {$[574]$} & {$[617]$} & {$[652]$} & [604] & [960] & [636] \\
\hline IL Resident & 5,483 & 3,822 & 4,592 & 12,417 & 296 & 8,897 \\
\hline $\begin{array}{l}\quad N=1523 \\
\text { Resident Outside of }\end{array}$ & {$[4,702]$} & {$[5,231]$} & {$[3,595]$} & {$[8,063]$} & {$[5,037]$} & {$[6,905]$} \\
\hline IL & 3,107 & $-3,433$ & $-2,509$ & 9,761 & $-2,905$ & 9,230 \\
\hline $\begin{array}{l}\quad N=4152 \\
\text { Conditional on }\end{array}$ & {$[2,377]$} & {$[2,709]$} & {$[2,768]$} & {$[8,048]$} & {$[1,889]$} & {$[4,172]^{*}$} \\
\hline Giving & 9,017 & $-2,322$ & $-12,255$ & 21,374 & $-4,244$ & 23,166 \\
\hline$N=2406$ & {$[4,274]^{*}$} & {$[5,789]$} & {$[9,723]$} & {$[11,025]$} & {$[4,252]$} & {$[7,622]^{* *}$} \\
\hline
\end{tabular}

$* p<0.05 ; * * p<0.01$

Notes: Table 3 explores alternative specifications and sub-samples of the data. Except where specifically noted, the included controls match those in Columns 2 and 4 of Table 2 . The first column of the table pools all the treatments. The remaining columns correspond to the five treatments and are estimated, in each row, from a single regression. For purposes of comparison, the top row of the table presents our baseline estimates. Empirical results are robust to corrections for multiple hypothesis testing in the spirit of List et al. (2016). 


\section{Appendix A: Solicitation Letter}

Dear Blank-

The twelve years l've spent as a faculty member at the University of Chicago have been the most intellectually stimulating and exciting years of my life. There is no other place in the world like it.

At Chicago Booth, I've been the Director of the Becker Center on Chicago Price Theory since its inception. Our mission is to demonstrate just how powerful Chicago-style economic thinking is as a tool for answering real-world problems. We do this through a combination of classroom teaching, public events, academic research, and popular writing.

With that mission in mind, I'm pleased to let you know that my latest book, Superfreakenomiss, has arrived on bookstore shelves this month.

With all the good fortune l've had and the attention I've received, finding the funds to carry out my research these days is not too difficult. When I was younger, however, that wasn't the case at all. Resources were always an issue.

Unfortunately, that is even more true today for our young faculty at Booth than it was for me when I was starting out. With budgets tight and government research funding shrinking, more and more of our faculty's time is devoted to trying to find ways to fund projects, taking away from the time spent doing the things that really matter: teaching and research. I think of young faculty like Emily Oster, who is doing cutting edge research on how economic factors influence the transmission of AIDS in Africa, Matt Gentzkow and Jesse Shapiro who have been studying the sources and consequences of media bias, and John List who is a pioneer in using randomized experiments in the study of business questions.

These young Booth faculty members, and dozens of others like them, have incredible ideas, limited only by their access to research funds. Gift support from you at this time, when budgets are particularly tight at Chicago Booth, could have a tremendous impact.

Regardless of whether you would like to make a gift at this time, we would love to keepyou informed about what's going on here at the Booth School. Towards that end, there is a reply card enclosed. Please let us know how you would most prefer to be kept in the loop. If you prefer you can email us at XXXXX, or call XXXXXX

With warmest regards,

Steve Levitt 


\section{Appendix B: Treatment Effects during Experimental Window}

\begin{tabular}{|c|c|c|c|c|}
\hline & Gift & Gift|Giving & Gift & Gift|Giving \\
\hline Pooled & 168.999 & 759.585 & 135.013 & 354.967 \\
\hline Treatments & {$[122.505]$} & [531.571] & {$[118.757]$} & [498.272] \\
\hline PreGift & & & $\begin{array}{c}0.001 \\
{[0.001]}\end{array}$ & $\begin{array}{c}0.018 \\
{[0.010]}\end{array}$ \\
\hline Illinois & & & $\begin{array}{c}246.639 \\
{[178.711]}\end{array}$ & $\begin{array}{c}309.259 \\
{[711.653]}\end{array}$ \\
\hline Warm & & & $\begin{array}{l}521.953 \\
{[132.610]^{* *}}\end{array}$ & $\begin{array}{l}-3,500.353 \\
{[2,644.642]}\end{array}$ \\
\hline MBA & & & $\begin{array}{l}-249.271 \\
{[497.935]}\end{array}$ & $\begin{array}{c}414.397 \\
{[714.610]}\end{array}$ \\
\hline _cons & $\begin{array}{l}376.475 \\
{[75.262]^{* *}}\end{array}$ & $\begin{array}{l}1,604.454 \\
{[320.097]^{* *}}\end{array}$ & $\begin{array}{l}-588.132 \\
{[254.225]^{*}}\end{array}$ & $\begin{array}{c}6,255.987 \\
{[4,980.118]}\end{array}$ \\
\hline $\begin{array}{l}\text { Controls } \\
R^{2}\end{array}$ & $\begin{array}{l}\text { No } \\
0.00 \\
5675\end{array}$ & $\begin{array}{l}\text { No } \\
0.00\end{array}$ & $\begin{array}{l}\text { Yes } \\
0.03\end{array}$ & $\begin{array}{c}\text { Yes } \\
0.15 \\
1246\end{array}$ \\
\hline$N$ & $\begin{array}{r}5675 \\
\text { Gift }\end{array}$ & $\frac{1246}{\text { Gift|Giving }}$ & $\begin{array}{l}5675 \\
\text { Gift }\end{array}$ & $\begin{array}{r}1246 \\
\text { Gift|Giving }\end{array}$ \\
\hline Book & $\begin{array}{c}516.333 \\
{[592.117]}\end{array}$ & $\begin{array}{c}1,527.448 \\
{[2,075.042]}\end{array}$ & $\begin{array}{c}539.805 \\
{[583.920]}\end{array}$ & $\begin{array}{r}976.226 \\
{[1,853.532]}\end{array}$ \\
\hline $\begin{array}{l}\text { Book and } \\
\text { Speaking }\end{array}$ & $\begin{array}{c}40.445 \\
{[195.511]}\end{array}$ & $\begin{array}{c}276.277 \\
{[785.977]}\end{array}$ & $\begin{array}{c}26.103 \\
{[191.002]}\end{array}$ & $\begin{array}{l}-574.692 \\
{[841.394]}\end{array}$ \\
\hline Speaking & $\begin{array}{c}106.020 \\
{[271.466]}\end{array}$ & $\begin{array}{c}82.577 \\
{[763.277]}\end{array}$ & $\begin{array}{c}104.480 \\
{[271.932]}\end{array}$ & $\begin{array}{l}-265.010 \\
{[643.688]}\end{array}$ \\
\hline $\begin{array}{l}\text { One-to- } \\
\text { One }\end{array}$ & $\begin{array}{c}290.436 \\
{[212.998]}\end{array}$ & $\begin{array}{c}1,317.630 \\
{[940.671]}\end{array}$ & $\begin{array}{c}252.259 \\
{[215.979]}\end{array}$ & $\begin{array}{c}996.712 \\
{[857.302]}\end{array}$ \\
\hline $\begin{array}{l}\text { Two-to- } \\
\text { One }\end{array}$ & $\begin{array}{c}34.590 \\
{[118.167]}\end{array}$ & $\begin{array}{c}256.340 \\
{[522.689]}\end{array}$ & $\begin{array}{c}-11.789 \\
{[114.028]}\end{array}$ & $\begin{array}{l}-174.623 \\
{[550.275]}\end{array}$ \\
\hline PreGift & & & $\begin{array}{c}0.001 \\
{[0.001]}\end{array}$ & $\begin{array}{c}0.018 \\
{[0.010]}\end{array}$ \\
\hline Illinois & & & $\begin{array}{c}251.196 \\
{[178.020]}\end{array}$ & $\begin{array}{c}345.961 \\
{[699.990]}\end{array}$ \\
\hline Warm & & & $\begin{array}{l}521.197 \\
{[132.694]^{* *}}\end{array}$ & $\begin{array}{l}-3,391.773 \\
{[2,596.796]}\end{array}$ \\
\hline MBA & & & $\begin{array}{l}-263.499 \\
{[498.696]}\end{array}$ & $\begin{array}{c}382.659 \\
{[729.593]}\end{array}$ \\
\hline _cons & $\begin{array}{l}376.475 \\
{[75.289]^{* *}}\end{array}$ & $\begin{array}{l}1,604.454 \\
{[320.613]^{* *}}\end{array}$ & $\begin{array}{l}-485.319 \\
{[266.143]}\end{array}$ & $\begin{array}{c}6,188.139 \\
{[4,711.235]}\end{array}$ \\
\hline $\begin{array}{l}\text { Controls } \\
R^{2}\end{array}$ & $\begin{array}{l}\text { No } \\
0.00\end{array}$ & $\begin{array}{l}\text { No } \\
0.00\end{array}$ & $\begin{array}{l}\text { Yes } \\
0.03\end{array}$ & $\begin{array}{l}\text { Yes } \\
0.15\end{array}$ \\
\hline$N$ & 5675 & 1246 & 5675 & 1246 \\
\hline
\end{tabular}

Notes: These regression results show that the treatment effects found for the extended time period after treatment do not come from donations during the treatment period. Coefficients for Giving Capacity, Mailings Received, Program, Degree, and Year Not Shown $* p<0.05 ;{ }^{* *} p<0.01$ 